\title{
Tegumentary leishmaniasis in Northern Argentina: distribution of infection and disease, in three municipalities of Salta, 1990-1992
}

\author{
Leishmaniose tegumentar na Argentina setentrional: distribuição da \\ infecção e da doença em três municípios de Salta, 1990-1992
}

\section{Sergio Sosa-Estani', Elsa Leonor Segura², Oscar Daniel Salomón', Adolfo Gómez', Mario Peralta ${ }^{3}$, Virgilio Coutada ${ }^{3}$ and Luis Medina Ruiz ${ }^{3}$}

\begin{abstract}
This work describes the epidemiological pattern of tegumentary leishmaniasis in an area north of Salta, Argentina. The prevalence and incidence were estimated by means of a cross-sectional study and two follow-up studies during two consecutive years. The Montenegro Skin Test (MST) was administered to 7336 subjects at baseline. The prevalence and incidence between 1990 and 1992 of infection (MST reactive) was 38\% persons and 4.5\% persons/year respectively. The prevalence and incidence of tegumentary leishmaniasis (presence of clinical signs) was $1.8 \%$ and $0.8 \%$ persons/year, respectively. A physical examination performed on 264 patients with MST reactive during three years revealed that 130 cases (49.2\%) had some evident sign of infection (scar and/or lesion), with a clinical presentation compatible with leishmaniasis. Our study demonstrated that after the epidemic outbreak of 1985 the transmission in the study area returned to endemic levels in 1992, and also demonstrated the presence of the asymptomatic infection in the area.
\end{abstract}

Key-words: Tegumentary leishmaniasis. Leishmaniasis.

Resumo O trabalho mostra o padrão epidemiológico da leishmaniose tegumentar em uma área no norte de Salta, Argentina. A prevalência e incidência foram estimadas através de um estudo transversal e dois estudos de seguimento durante dois anos consecutivos. A Intrademorreação de Montenegro (IDRM) foi aplicada a 7.336 pessoas no estudo de base. A prevalência e incidência entre 1990 e 1992 da infecção (IDRM reativa) foi de 38\% pessoas e 4,5\% pessoas/ano respectivamente. O exame físico realizado em 264 pacientes com IDRM reativa durante 3 anos, revelaram que apenas 130 casos (49,2\%) tiveram algum signo evidente de infecção (cicatriz ou lesão), com uma apresentação clínica compatível a leishmaniosis. Nosso trabalho mostrou que após o surto epidêmico em 1985, a transmissão na área de estudo retornou aos níveis endêmicos em 1992, e também demonstrou a presença da infecção assintomática na região.

Palavras-chaves: Leishmanioses tegumentar. Leishmanioses.

\footnotetext{
1. Centro Nacional de Diagnóstico e Investigación de Endemoepidemias (CeNDIE)/ Administración Nacional de Laboratorios e Institutos de Salud (ANLIS) "Dr. Carlos G. Malbrán, 2. ANLIS Dr. Carlos G. Malbrán”, Secretaría de Salud, Ministerio de Salud y Acción Social de la Nación, Buenos Aires, Argentina 3. Ministerio de Salud, Provincia de Salta, Argentina.

Finantial support: This work was supported by Trainning and Research on Tropical Diseases (TDR) UPND/WB/WHO/TDR. National Public Health Ministery from Argentina.

Address to: Dr. Sergio Sosa-Estani, National Center of Diagnosis and Endemic and Epidemic Research. Av. Paseo Colón 568, 1063, Buenos Aires, Argentina.

Telefax: (54-11) 4331-2536.

E-mail: ssosaestani@abaconet.com.ar

Recebido para publicação em 10/6/99.
} 
Leishmaniasis is classified as a subtropical disease. Worldwide, there are an estimated 350 million people at risk of contracting the disease and a total of approximately 12 million people affected by it ${ }^{40} 41$.

The predominant clinical form of the disease found in Argentina is the Tegumentary leishmaniasis (TL) with expression Cutaneous (CL) and Mucocutaneous (MCL) 19263335 . Parasites isolated and identified so far from patients in Argentina belong to the braziliensis complex 7263233 . Lutzomyia intermedia is the suspected vector of Leishmania in northwestern Argentina ${ }^{2829}$.

Between 1950 and 1980, approximately 80 annual cases of leishmaniasis were reported throughout Argentina. The number of cases increased fivefold from 1983 to $1987{ }^{35}$ signaling the existence of an epidemic outbreak. This was further confirmed by case reports published in $1992^{3}$. The outbreak occurred mainly in the Departments of San Martin (Embarcación and General Mosconi Counties) and Orán (Pichanal County), Salta Province. The highest incidence was reported in Pichanal, the cases appeared mainly in periurban areas. In 1988, cases started to decrease until 1997. During 1997, a new increase in the province of Salta was observed, with $273(72 \%)$ cases reported out of a total of 379 cases countrywide. The last outbreak foci are currently under study, and so far, have been attributed to logging activities.

The objective of this paper is to describe the age and gender distribution of prevalence and incidence of TL in Salta, within the area of greater transmission of Leishmania in Argentina.

\section{MATERIAL AND METHODS}

Study area. The area of study is located in the northeastern region of the province of Salta, Argentina (22 $\left.30^{\prime}-24^{\circ} 10^{\prime}, 63^{\circ} 10^{\prime}-64^{\circ} 25^{\prime}\right)$ in three municipalities: General Mosconi and Embarcación (Department of San Martin), and Pichanal (Department of Orán). Pichanal and Embarcación are the municipalities where rise in incidence had occurred during the 1984 epidemic, and General Mosconi, which had the lowest incidence rates in the same period ${ }^{36}$. The area covers approximately $6,400 \mathrm{~km}^{2}, 68$ localities and has a population of 40,000 inhabitants. It is part of a phytogeographic region called Yunga ${ }^{22}$. Temperatures range from a minimum of $0^{\circ} \mathrm{C}$ to a maximum of $40^{\circ} \mathrm{C}$. Rainfall 800 to $1000 \mathrm{~mm}$ annually ${ }^{11}$.

Study design. In order to estimate disease prevalence and incidence, the study combined a cross-sectional study of a sample of the population with a follow-up study of the same individuals, so that there were one baseline and two followup observations carried out at 12 and 24 months after baseline.

Sample size. The sample size was calculated assuming a $5 \%$ estimated prevalence, and a confidence level of $90 \%(1-\alpha)$ and a power of $80 \%$ $(1-\beta)^{9}$. This sample was estimated at 10,000 subjects, or $25 \%$ of the total population of the study area. The sampling units were the dwelling and the analyze units were the dwelling and all inhabitant of select dwellings. A simple random sampling design was carried out for the selection of dwellings.

Baseline study. Between June and October 1990 , the following tasks were carried out as part of the study either about the selected dwellings or its inhabitants: a) a physical examination of the skin, and nasal and oral mucous, and b) Montenegro skin test (MST) ${ }^{37}$.

Diagnostic procedures. In patients with clinical symptoms, the diagnose was confirmed by parasitological tests (smear, culture from aspirate and biopsy, and hamster inoculation) ${ }^{30}{ }^{32}$. Attempts were also made to isolate the parasite from the aspirate samples

Montenegro skin test (MST). We utilized as Montenegro antigen a preparation of leishmanine produced from dead parasites of the species Leishmania panamensis and Leishmania amazonensis, in a final concentration of $2 \times 10^{6}$ promastigotes $/ \mathrm{ml}^{37}$. The test was performed by applying $0.1 \mathrm{ml}$ of leishmanine provided by the International Center of Training and Medical Research (CIDEIM, Cali, Colombia). Test readings were performed 48 hours later; readings were accepted for up to 72 hours. The MST was considered to be reactive when the induration measure, was $0.5 \mathrm{~cm}$ or larger in diameter ${ }^{37}$.

All patients presenting a reactive Montenegro test were defined as infected with Leishmania. In the absence of active lesions or scars, the infection was considered asymptomatic. The infection was classified as symptomatic in the presence of a reactive test and, active lesion or typical scar, or clinical, therapeutical or parasitological positive diagnosis.

Follow-up. All the sample dwellings were visited during June-August 1991, and again in 1992. 
On this occasion, information about migration was registered, in order to discard possible bias in the sample due to temporary work related migration in the area during the base study.

The MST was administered to patients who were negative or had not received the test in previous surveys. A physical examination was also conducted in all the population under study to determine whether subjects presented signs which might suggest leishmaniasis.

The exposure period to acquire the infection was calculated taking into account the interval between two or three non-reactive MST tests, in individuals who presented non-reactive results successively. For persons who converted from non-reactive to reactive, the exposure period was estimated since the first non-reactive test. When the first non-reactive result was determined in the baseline study and only the third survey was carried out with reactive result, the exposure period was estimated from the midpoint of the interval between the two.

Analysis of data. The $\chi^{2}$ test and $\chi^{2}$ ManthelHanzel was used to compare proportions and trend respectively. Was considered an association statistically significant, for a level of confidence of $90 \%{ }^{9}$.

\section{RESULTS}

A total of 1,840 dwellings were visited in the baseline study. The average (SD) number of residents per dwelling was $5.7( \pm 3.7)$. The sample selected in Pichanal included 3,102 individuals; in Embarcación 4,025 and, in General Mosconi, 2,822 people. The age and sex distribution did not differ significantly among the different sites. MST was administered to 7,336 (73.7\%) individuals interviewed, and of those, in 7,322 $(73.6 \%)$ were carried out exam of skin and mucous membranes of mouth and nasofarinx.

Of those examined in the baseline study, 278 (37.9\%) people had a reactive test, this represented a total prevalence of infection of (Table 1). The prevalence increased steadily with age, up to the age group of 50-59 years. The $\chi^{2}$ for trend was $112.9(p<0.00001)$. The highest prevalence (53.3\%) was observed in Pichanal.

The prevalence of TL in 1990 was of $1.8 \%$ 。 population, with the highest rate occurring among the population $50-59$ years of age $(5.4 \%$ o). There were no cases detected in this sample among the age groups $30-39$ and $40-49$ years old. The rural area of Embarcacion presented the highest prevalence: $3.6 \%$. No significant differences in prevalence were observed by sex, area or sector of residency (Table 1).

The total incidence rate of infection for the study period (1990 to 1992) was $4.5 \%$ o persons/ year. The highest rates were observed among those 60 years of age or older $(17.6 \%$ ); the rate among the group of under 10 years of age was $3.3 \%$. The $\chi^{2}$ for trend was $10.9(p<0.001)$ (Table 1). There was no significant difference by sex ( $p$ $>0.10)$. The greatest difference among the incidence rates of a single municipality was observed between the rural and peri-urban sectors of General Mosconi $(p<0.10)$ (Table 1).

The total incidence of TL for the period June 1990 -August 1992 was $0.8 \%$. The highest incidence rate of TL occurred in the age groups 40-49 and 50-59 years. The $\chi^{2}$ for trend was 3.8 $(p<0.10)$ (Table 1).

Incidence rates of TL were higher in Pichanal and Embarcación (1.2 and 1.0\%o, respectively) than in General Mosconi (0.3\%o). These rates were similar in the peri-urban and rural sectors. However, the peri-urban area of Pichanal had the highest absolute incidence (1.3\%), followed by the rural sector of Embarcación (1.1\%o).

The presence of clinical signs, such as typical scars, appeared significantly associated with MST reactivity $\left(\chi_{M-H}^{2} 114.3, p<0.0001\right)$, and the presence of lesions $\left(\chi_{M-H}^{2} 59.0, p<0.0001\right)$.

Among the 264 individuals with physical examination and reactive MST, 49.2\% (130/264) showed some clinical sign (scar and/or lesion) compatible with leishmaniasis. These were located most frequently on the legs (44.6\%), followed by the arms (25.4\%), multiple location (14.6\%), trunk (10.0\%), head (6.2\%), and mucous membranes (1.5\%). In three cases with lesions in mucous tissue (two) and cutaneous tissue (one), the patients presented cutaneous scars. The rest had no evidence of cutaneous or mucosal forms of the disease.

A total of 102 individuals with a positive MST and signs of infection, provided information about the year of onset of the lesion that originated the scar. Of those, $86.3 \%(88 / 102)$ indicated that the years when appeared the lesion were between 
Table 1 - Prevalence (1990) and Incidence (1990-1992) rates of MST reactive (suspected infection) and Tegumentary leishmaniasis by age, sex and Municipality of residence. Salta, Argentina, 1990-1992.

\begin{tabular}{|c|c|c|c|c|c|c|c|c|}
\hline & \multicolumn{2}{|c|}{$\begin{array}{c}\text { Prevalence of } \\
\text { infection }\end{array}$} & \multicolumn{2}{|c|}{$\begin{array}{l}\text { Prevalence } \\
\text { of } T L\end{array}$} & \multicolumn{2}{|c|}{$\begin{array}{c}\text { Incidence of } \\
\text { infection }^{\mathrm{a}}\end{array}$} & \multicolumn{2}{|c|}{$\begin{array}{l}\text { Incidence } \\
\text { of } \mathrm{TL}^{\mathrm{b}}\end{array}$} \\
\hline & $\begin{array}{c}\text { population } \\
\text { studied }\end{array}$ & $\begin{array}{l}\text { rate \%。 } \\
\text { studied }\end{array}$ & $\begin{array}{c}\text { population } \\
\text { studied }\end{array}$ & $\begin{array}{l}\text { rate \%॰ } \\
\text { studied }\end{array}$ & population & rate $\%$ & population & rate \%。 \\
\hline \multicolumn{9}{|l|}{ Age group } \\
\hline $0-9$ & 2725 & 12.1 & 2725 & 2.2 & 3357 & 3.3 & 6386 & 0.3 \\
\hline $10-19$ & 1685 & 36.2 & 1684 & 1.8 & 1914 & 4.2 & 4039 & 0.7 \\
\hline $20-29$ & 931 & 48.3 & 930 & 2.2 & 935 & 1.1 & 2120 & 0.9 \\
\hline $30-39$ & 847 & 48.4 & 847 & 0.0 & 957 & 4.2 & 2036 & 1.0 \\
\hline $40-49$ & 509 & 84.5 & 507 & 0.0 & 546 & 9.2 & 1186 & 2.5 \\
\hline $50-59$ & 379 & 92.3 & 372 & 5.4 & 424 & 9.4 & 926 & 2.2 \\
\hline 60 or more & 260 & 76.9 * & 257 & 0.0 & 284 & $17.6^{*}$ & 648 & 0.0 ** \\
\hline Total & 7336 & 37.9 & 7322 & 1.8 & 8417 & 4.5 & 17341 & 0.8 \\
\hline \multicolumn{9}{|l|}{ Gender } \\
\hline Men & 3318 & 35.9 & 3311 & 2.4 & 3681 & 4.9 & 7922 & 1.1 \\
\hline Women & 4018 & 39.6 & 4011 & 1.2 & 4736 & 4.2 & 9419 & 0.5 \\
\hline \multicolumn{9}{|l|}{ Municipality } \\
\hline Pichanal & 2045 & 53.3 & 2037 & 1.5 & 1731 & 3.5 & 4307 & 1.2 \\
\hline Periurban & 1454 & 55.7 & 1450 & 1.4 & 1284 & 3.9 & 3130 & 1.3 \\
\hline Rural & 591 & 45.7 & 587 & 1.7 & 447 & 2.2 & 1177 & 0.8 \\
\hline Embarcación & 2810 & 31.3 & 2809 & 2.1 & 3376 & 5.0 & 6987 & 1.0 \\
\hline Periurban & 1704 & 21.1 & 1706 & 1.2 & 2064 & 4.8 & 4240 & 0.9 \\
\hline Rural & 1106 & 47.0 * & 1103 & 3.6 & 1312 & 5.3 & 2747 & 1.1 \\
\hline Gral. Mosconi & 2481 & 32.6 & 2476 & 1.6 & 3310 & 4.5 & 6047 & 0.3 \\
\hline Periurban & 1575 & 21.0 & 1573 & 1.9 & 2130 & 2.8 & 3839 & 0.0 \\
\hline Rural & 906 & $53.0 *$ & 903 & 1.1 & 1180 & $7.6^{\star \star *}$ & 2208 & 0.9 \\
\hline
\end{tabular}

a Positive MST with a prior negative reading. Observation period: 1990-1992.

b Leishmaniasis manifestation after onset of study (June 1990). Observation period: August-October 1990, June-August 1991, JuneAugust 1992.

${ }^{* * *} \mathrm{p}$ value $<0.10^{* *} \mathrm{p}$ value $<0.05{ }^{*} \mathrm{p}$ value $<0.001$.

1980 and 1993, with higher percentages in 1986 (14.0\%) and 1990 (14.0\%).

The prevalence of reactive MST in the population under 30 years of age in Pichanal and General Mosconi was greater among women $(p$ $<0.05)$, for the 20-29 and 10-19 year age groups respectively (Figure 1). Among the population 30 years of age or older, the prevalence was higher among men in the three study areas within the group of 50-59 years of age in Pichanal; 40-49 years old in Embarcación, and 30-39 years old in General Mosconi (Figure 1).

The results by area of residence indicated that only the peri-urban sector of Pichanal had a higher prevalence among women than men $(p<$
0.10) (Figure 2). The prevalence rates observed were higher for rural women of Embarcación and Gral Mosconi, when compared to those of the peri-urban sectors (Figure 2).

Among 264 patients with reactive-MST in the baseline, $50.8 \%$ did not show any clinical sign (scar or lesion). The asymptomatic infection was highest in the age group 40-59 years (Figure 3a).

Of 38 incident cases of infection (MST conversion) during the study period, only $29 \%$ presented lesions of TL (Figure 3b). The remaining cases had no evidence of the cutaneous or mucosal forms of the disease. The incidence of asymptomatic infection was observed most frequently in the 30 59 year age group. 

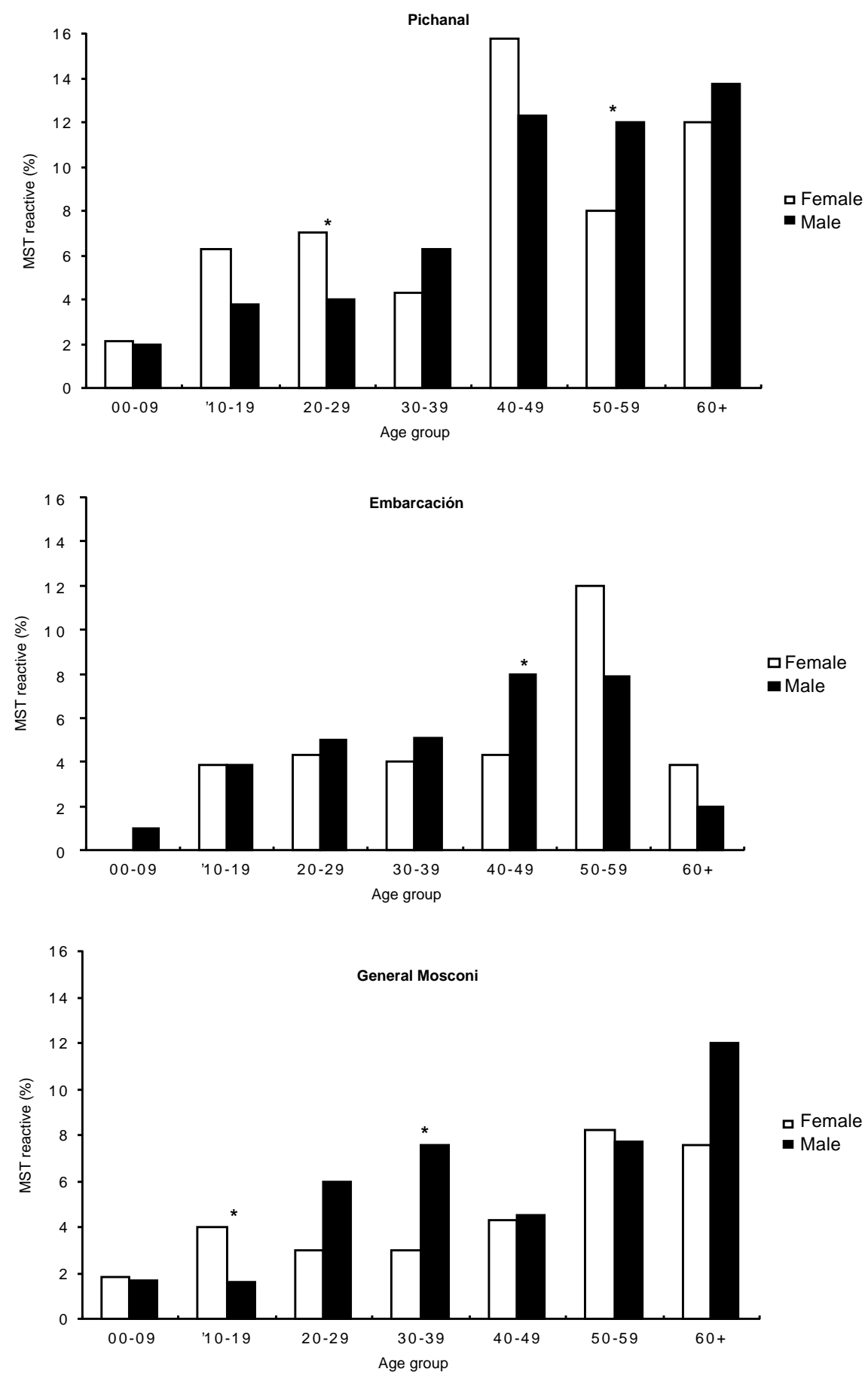

* significative difference $p<0.0$

Figure 1 - Prevalence rate (\%) of Leishmania infection (MST reactive), in three municipalities of an endemic leishmaniasis area. Salta, Argentina, 1990. 

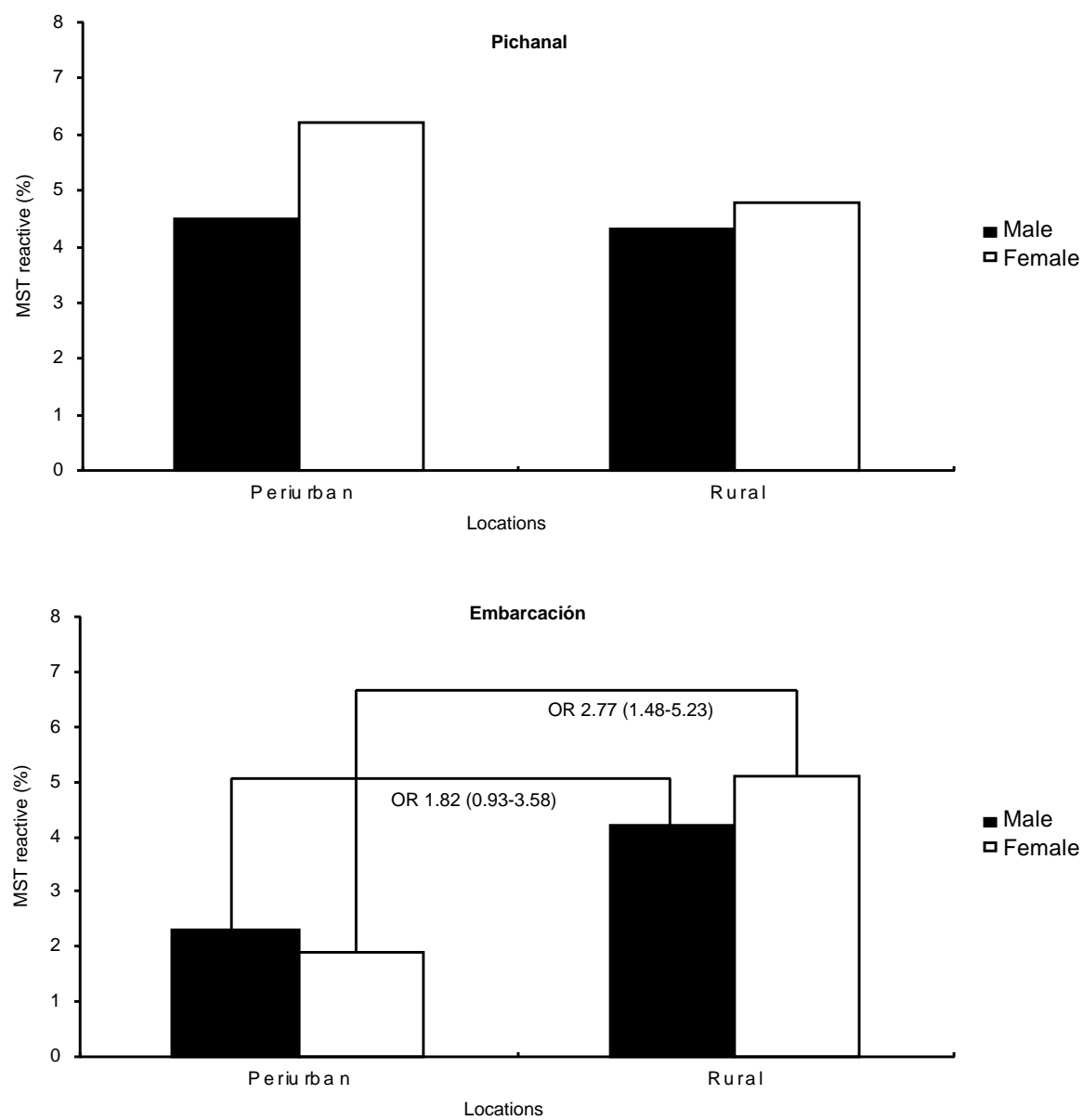

- Male

口Female

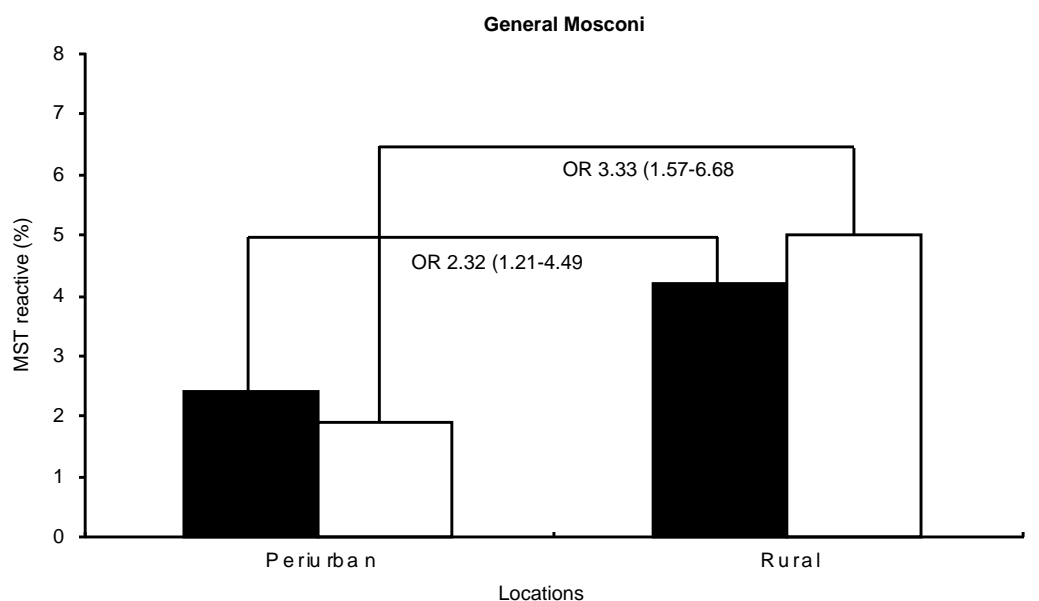

- Male

- Female

Figure 2 - Prevalence rate (\%) of Leishmania infection (MST reactive), by sex and place of residence, in three municipalities of an endemic leishmaniasis area. Salta, Argentina 1990. 


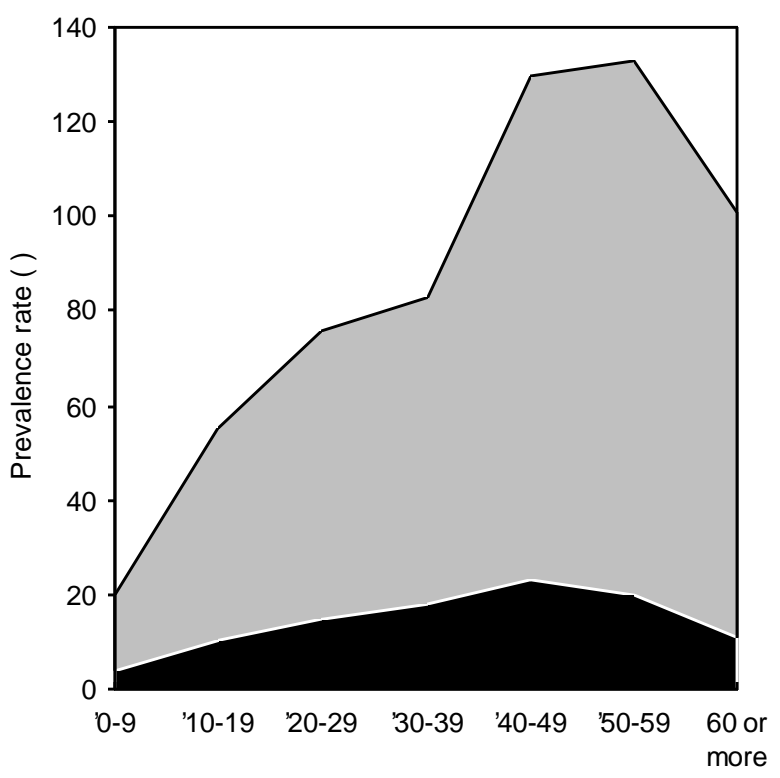

Age group

- Tegumentary leishmaniasis $\square$ Montenegro skin test

Figure 3a - Prevalence rate (\%) of Leishmania infection (MST reactive) and Tegumentary leishmaniasis (scar/lesion) in 264 patients, by age group, in an endemic area. Salta, Argentina, 1990.

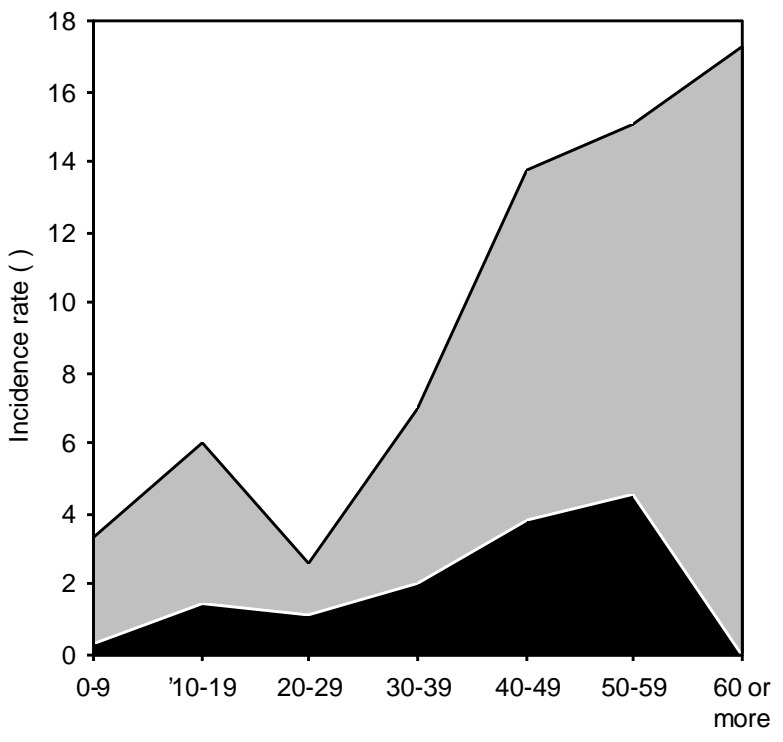

Age group

- Tegumentary leishmaniasis $\square$ Montenegro skin test

Figure $3 b$ - Incidence rate of Leishmania infection (MST conversion), and Tegumentary leishmaniasis (lesion) in 38 patients, by age group in an endemic leishmaniasis area. Salta, Argentina, 1990-1992. 


\section{DISCUSSION}

This work describes the incidence and prevalence of TL in the north of Salta, Argentina. Among cases with prevalent infection in 1990, $49.2 \%$ presented some clinical sign (scar and/or lesion). In addition, only $28.9 \%$ of cases with incident infection were symptomatic. Even when considering the possible existence of recent cases who have not yet developed cellular immunity, this finding confirms the presence of asymptomatic infection; this should be taken into account for the differential diagnosis of cases living in endemic areas. The simple association of positive MST and a suspect lesion can lead to misdiagnosis, especially in the presence of an asymptomatic leishmaniasis infected patient who has a concomitant lesion from a different etiology. These data agree with the findings of other authors ${ }^{27} 3839$. They are disputed, as well, by other observations in which the reactivity of the MST is narrow and almost exclusively related to the presence of clinical signs, scars or lesions ${ }^{114}$ This could be attributed to immunological characteristics of the patient, his or her history of contact with the parasite, the parasite strain 281639 and genetic characteristics of the host ${ }^{31}$.

The prevalence of infection in the population of Pichanal was higher than in the other two municipalities, which agrees with the history of transmission during the epidemic outbreak ${ }^{35}$. This prevalence shows an increasing trend with age, similar to that observed by other authors at other foci ${ }^{1514172038}$. This fact is explained by the cohort effect, lengthier periods of exposure, and traditional transmission patterns related to forest activities in the study area.

The prevalence and incidence rates in children and young women would indicate a dynamic of domicile and/or surrounding area transmission, at least during outbreaks. This situation has been observed by other authors who have described alternate or overlapping transmission cycles between in-house and surrounding areas, associated with forestry work ${ }^{1314153539}$.

The risk of infection related to residence in rural area observed in Embarcación and General Mosconi was not seen in Pichanal suggests two transmission patterns in the region during the outbreak: a rural/ jungle pattern in Embarcación and General Mosconi, and a peri-urban pattern in Pichanal. This is compatible with the variation in the relative density of the insect vector in each area, given variations in landscape characteristics and proximity to probable breeding sites of Phlebotomine ${ }^{28}$. This must be taken into account when proposing possible control measures for leishmaniasis. It should be mentioned that, in General Mosconi, the risk of infection for rural residents might be linked to landscape characteristics surrounding the home, which contribute to maintaining transmission. This aspect distinguishes General Mosconi from other areas $^{12}$

The results presented here show the magnitude of Leishmania transmission in an endemic region, as reflected by low prevalence and incidence rates after an epidemic outbreak. Patterns of transmission currently observed correspond to isolated cases in peri-urban areas ${ }^{6} 1318212324343539$. More frequently, however, patterns reflect the occurrence of human adult cases and/or canine cases due to contact with the forest, whether because of residence in such areas or to incursion for work related reasons ${ }^{15193335}$. A decrease in the number of new cases following a significant increase is considered a natural post-epidemic process, and a consequence of a diminishing number of hosts still susceptible to the etiologic agent ${ }^{10}$.

On the other hand, the outbreaks registered in the area in recent years ${ }^{42}$, and those currently under study, seem to be related to specific and sporadic environmental changes (logging or forestry activities), to human activities in such environments, or to human settlements (dwellings) in the vicinity of the altered area.

Given the endemic situation of leishmaniasis in Argentina, strengthening of case detection activities is recommended. While transmission remains at constant levels, the main control strategy should be early detection and treatment of patients with active infection, even in the presence of sporadic outbreaks.

\section{ACKNOWLEDGEMENTS}

To Dr. E Richter of the Ministry of Health of Salta. E Perez, D Cruz, E Leon, C Talero, R Abraham, J Aguirre, CA Arraya, W Mendivil and the staff of the primary health care system and Ministry of Health hospitals of Salta in General Mosconi, Embarcacion, and Pichanal. To Nilda Alonso, Ester Albacette, Dario Paez (INP Dr. Mario Fatala Chaben) and Victor Vigil, Adolfo Contreras, Alberto Liendo (National Chagas Service) for their technical collaboration in the field. Professional and technical staff of the 
National Institute of Parasitology Dr. Mario Fatala Chaben for its field and laboratory support. To the Municipality of Embarcación for its logistical support during the team's permanence in the study area. To Dr. Roberto Chuit and the National Chagas Service, staff the National Malaria Service and the Battalion of the Argentine Army of Tartagal, Salta for its total support in operational field. To the International Center of Training and Medical Research (CIDEIM), Cali, Colombia, for supplying leishmanine in the first stage of research. To Mrs. Roxane Gonzales for the traduction and Dr. Ricardo Gurtler for helpful comments.

\section{REFERENCES}

1. Andrade-Navaez FJ, Simmonds-Diaz E, Rico-Aguilar S, Andrade-Narvaez M, Palomo-Cetina A, Canto-Lara S, Garcia-Miss M, Madera-Sevilla M, Albertos-Alpuche N. Incidence of localized cutaneus leishmaniasis (chiclero's ulcer) in Mexico. Transaction of the Royal Society of Tropical Medicine and Hygiene 84:219-220, 1990.

2. Badaro R, Jones TC, Carvalho EM, Sampaio D, Reed SG, Barral A, Teixeira R, Johnsosn WD Jr. New Perpectives on a Subclinical form of visceral leishmaniasis. Journal of Infectious Disease 154:10031011, 1986.

3. Boletín Epidemiológico Nacional Secretaría de Salud. Ministerio de Salud y Acción Social de la Nación. República Argentina, 1985-1992.

4. Campanini A, Sinagra A, Saravia N, Arevalo J, Lina C, Sosa Estani S, Salomón D, Segura EL. Caracterización in vitro de aislados de Leishmania de pacientes de Salta. Medicina (Bs.As.) 53 (Supl I):81, 1993.

5. Campos M, Henriquez R, Limpias L, Sanchez A, Giraldo A. Leishmaniasis tegumentaria en El Huila. Acta Médica Colombiana; 10:15-21, 1985

6. Coutinho S, Nunes MP, Marzochi MC, Tramontano N. A survey for American cutaneous and visceral leishmaniasis among 1,342 dogs from areas in Rio de Janeiro (Brazil) where the human diseases occur. Memórias do Instituto Oswaldo Cruz 80:17-22, 1985.

7. Cuba CA, Torno CO, Ledesma O, Visciarelli E, Garcia S, Prat MI, Costamagna R, Barbieri L, Evans DA. Human cutaneous leishmaniasis caused by Leishmania (Viannia) braziliensis in Santiago del Estero, Argentina: identification of parasites by monoclonal antibodies and isoenzymes. Revista do Instituto de Medicina Tropical de São Paulo 38:413-442, 1996.

8. Davies CR, Llanos-Cuentas EA, Sharp SJ, Canales J, Leon E, Alvarez E, Roncal N, Dye C. Cutaneous leishmaniasis in the Peruvian Andes: factors associated with variability in clinical symptoms, response to treatment, and parasite isolation rate. Clinical Infectious Diseases 25:302-310, 1997.

9. Fleiss JL. Statistical Method for Rates and Proportions, $2^{\text {nd }}$ edition, John Wiley \& Sons, 1981.

10. Franca F, Lago EL, Tada S, Costa JM, Vale K, Oliveira J, Costa MA, Osaki M, Cheever L, Netto EM. An outbreak of humna Leishmania (Viannia) braziliensis infection. Memórias do Instituto Oswaldo Cruz 86:169-174, 1991.
11. Fuerza Aerea Argentina, Servicio de Metorológico Nacional. Boletín climatológico, vol II, nº 1-12, 1990.

12. Gómez A, Sosa Estani D, Salomón D, Segura EL. Leishmaniasis en Argentina. Aspectos sociales. Medicina (Buenos Aires) 53 (Supl I):88-89, 1993.

13. Gramicia M, Bettini L, Gradoni P, Ciarmoliml, Verrilli S, Loddo S, Cicalo C. Leishmanisis in Sardinia. 5. Leishmanin reaction in the human population of a focus of low endemicity of canine leishmaniasis. Transaction of the Royal Society of Tropical Medicine and Hygiene 84, 371-374, 1990.

14. Hashiguchi Y, Arias O, Maciel D, Mansur J, Furuya M, Kawabata M. Cutaneus leishamaniasis in south-eastern Paraguay: a study of an endemic area at Limoy. Transaction of the Royal Society of Tropical Medicine and Hygiene 85:592-594, 1991.

15. Herrer A, Christenses HA. Epidemiological patterns of cutaneous leishmaniasis in Panamá I. Epidemics among samall roups of settler. Annals of Tropical Medicine Parasitology 70:59-65, 1976.

16. Llanos Cuentas AE, Marsden PD, Lago EL, Barreto AC Cuba Cuba C, Johnson WD. Human mucocutaneous leishmaniasis in Tres Braços, Bahia, Brazil. An area of Leishmania braziliensis braziliensis transmission II. Cutaneous disease. Presentation and evolution. Revista da Sociedade Brasileira de Medicina Tropical 17:169-177, 1984.

17. Marty P, Le Fichoux Y, Giordana D, Brugnetti A. Leishmanin reaction in the human population of higly endemic focus of canine Leishmanisis in Alpes maritimes, France. Transaction of the Royal Society of Tropical Medicine and Hygiene 86:249-250, 1992.

18. Mayrink W, Willams $P$, Coelho MV, Martins AV, Magalhães PA, Costa CA, Falcão AR, Melo MN, Falcão AL. Epidemiology of dermal leishmaniasis in the Rio Doce Valley, Minas Gerais, Brazil. Annals of Tropical Medicine Parasitology 73:123-137, 1979.

19. Mazza S, 1926a. Leishmaniasis tegumentaria y visceral. Boletin Del Instituto de Clínica Quirúrgica (Buenos Aires); 13:208-216, 1979.

20. Naiff R, Barrett T, Arias J, Naiff M. Encuesta Epidemiológica de Histoplasmosis, paracoccidioidomicosis y leishmaniasis mediante pruebas cutaneas. Boletin de la Oficina Sanitaria Panamericana 104:36-49. 1988. 
21. Oliveira-Neto MP, Pirmez C, Rangel E, Schubach A, Grimaldi Jr G. An outbreack of american cutaneous leishmaniasis (Leishmania braziliensis braziliensis) in an periurban area of Rio de Janeiro City, Brazil: clinical and epidemiolgical studied. Memórias do Instituto Oswaldo Cruz 83:427-435, 1988.

22. Parodi LR. Las regiones fitogeográficas argentinas. In: Enciclopedia argentina de agricultura y ganaderia, ACME S.A.C.I., Bs.As., vol III, Cap. 1:1-14, 1964.

23. Passos VM, Falcão AL, Marzochi MCA, Gontijo CM, Dias ES, Barbosa-Santos EGO, Guerra HL, Katz N. Epidemiological aspects of american cutaneous leishmaniasis in a periurban area of the metropolitan region of Belo Horizonte, Minas Gerais, Brazil. Memórias do Instituto Oswaldo Cruz 88:103-110, 1993.

24. Passos VM, Andrade AC, Silva ES, Figueiredo EM, Falcão AL. A canine survey in a recent focus of cutaneous leishmaniasis in the city of Sabará, the metropolitan area of Belo Horizonte. Revista da Sociedade Brasileira de Medicina Tropical 29:323-329, 1996.-

25. Quintana H, Etcheverry JB. Leishmaniosis Americana en la Provincia de Jujuy. In: Actas y trabajos. I Congreso Nacional de Medicina 2:847-860, 1917.

26. Ripoll C, Remondegui C, Romano F, Rivetti E. Leishmansis, situación actual en la Provincia de JujuyArgentina. In: Resumen III Congreso Argentino de Protozoología, Buenos Aires, Argentina. p.41, 1990.

27. Ripoll C, Romano F, Ubeid C, Nuñez J, Molina M, Remondegui C. Leishmaniasis: encuesta epidemiológica por Intradermoreacción de Montenegro. Jujuy, Argentina. In: Resumen IV Congreso Argentino de Protozoología, Catamarca, Argentina, 1993.

28. Salomón OD. Phlemotomine sandflies at a leishmaniasis focus in Argentina. Thesis for the Degree of Master of Public Health, Faculty of the Department of Epidemiology and Public Health, Yale University, Connecticut, USA, p.149-152,1997.

29. Salomón OD, Zaidemberg M. Brote de leishmaniasis cutánea americana (LCA) en la provincia de Salta, 1993. Parte III Aspectos entomológicos. Medicina (Buenos Aires) 57 (supl. III):48, 1997.

30. Senekjie HA. Studies on the culture of Leishmania tropica. Transaction of the Royal Society of Tropical Medicine and Hygiene 33:267-269, 1939.

31. Shaw MA, Davies CR, Llanos-Cuentas EA, Collins A. Human genetic susceptibility and infection with Leishmania peruviana. American Journal of Human Genetics 57:1159-1168, 1995.
32. Sinagra A, Riarte A, Luna C, Campanini A, Segura EL. Leishmania (Viannia) braziliensis: biological behavior in golden hamsters of isolates from argentine patients. American Journal of Tropical Medicine and Hygiene 57:115-118, 1997.

33. Sosa Estani S, Campanini A, Sinagra A, Luna C, Peralta M, Coutada V, Medina L, Riarte A, Salomón OD, Gomez A, Segura EL. Caracteristicas clínicas y diagnóstico de la Leishmaniasis mucocutanea en pacientes de una área endémica de Salta, Argentina. Medicina (Buenos Aires) 58:685-691, 1998.

34. Sousa WJ, Sabroza PC, Santos CS, de Sousa E, Enrique MI, Coutinho SG. Montenegro skin test for American cutaneus leishmaniasis carried out on school children in Rio de Janeiro, Brazil: an indicator of transmission risk. Acta Tropica (Basel) 52:111-119, 1992.

35. Villafañe R. Leishmaniasis cutanea. Informe técnico B41. Dirección General de Epidemiología, Secretaría de Estado de Salud Pública, Ministerio de Bienestar Social, Provincia de Salta, Agosto, 1987.

36. Villafañe R, Richter EE, Soave de Richter. Análisis crítico de la epidemia de leishmanisis, años: 1985-87. Provincia de Salta - República Argentina. Dirección General de Epidemiología, Ministerio de Salud Pública, Salta, 1988.

37. Weigle KA, Valderrama L, Arias AL, Santrich C, Saravia NG. Leishmanin skin test standarization and evaluation of safety, dose, storage, longevity of reaction and sensitization. American Journal of Tropical Medicine and Hygiene 44:260-271, 1991.

38. Weigle KA, Santrich C, Martinez F, Valderrama L, Saravia NG. Epidemiology of cutaneous leishmaniasis in Colombia: a longitudinal study of the natural history, prevalence, and incidence of infection and clinical manifestations. Journal of Infectious Disease 168:699-708, 1993.

39. Weigle KA, Santrich C, Martinez F, Valderrama L, Saravia NG. Epidemiology of cutaneous leishmaniasis in Colombia: environmental and Behavioral risk factors for infection, clinical manifestations, and pathogenecity. Journal of Infectious Disease 168:709-714, 1993.

40. World Health Organization,. Control of the leishmaniasis. Report of a WHO Expert Comittee. Technical Report Series nํ 793. WHO, Geneve, Switzerland, 1990.

41. World Health Organization. Division of Control of Tropical Diseases. Disease sheet: Leishmaniasis (main). Last up date is July $31,1995$.

42. Zaidemberg M, Salomón D. Brote de leishmaniasis cutánea americana (LCA) en la provincia de Salta, 1993. Parte I Aspectos epidemiológicos. Parte II Aspectos clínicos y diagnóstico. Medicina (Buenos Aires) 57 (supl III):48, 1997. 